SVU- International Journal of Veterinary Sciences, 1 (2): 85-94, 2018.

Print ISSN: 2535-1826

Online ISSN: 2535-1877

Research Article

Open Access

\title{
Effect of Epidermal Growth Factors (EGF) on the Maturation and Developmental Competence of Buffalo's Oocytes and Embryo Stages in vitro
}

\section{Nasra A.Yousef ${ }^{1}$, Hassan A. Hussein ${ }^{2}$, Magdy R. Badr ${ }^{3 *}$, Ahmed Ezzat Ahmed 1,4}

${ }^{1}$ Department of Theriogenology, Faculty of Veterinary Medicine, South Valley University, 83523 Qena, Egypt, ${ }^{2}$ Department of Theriogenology, Faculty of Veterinary Medicine, Assuit University,71515, Assuit, Egypt, ${ }^{3}$ Animal Reproduction Research Institute (ARRI), ELHaram, Giza, Egypt, ${ }^{4}$ Biology Department, Faculty of Science, King Khalid University, 61413 Abha, Saudi Arabia.

Abstract

The present study aims to study the effects of epidermal growth factors (EGF) supplementations to the in vitro maturation (IVM) medium of buffalo's oocytes on the oocyte maturation rate and embryo development competence. The ovaries were collected from ElMonieb slaughters house and transferred directly to the laboratory for the experiment processing. Excellent and good cumulus oocytes complexes (COCs) were aspirated from 3-8 mm diameter follicles. TCM-199 medium were used for in vitro maturation. In experiment I, COCs were incubated in EGF-containing IVM medium as; 0 (control or CTL), 10, 20 and $50 \mathrm{ng} / \mathrm{ml}$ EGF for $24 \mathrm{hrs}$ at $38.5^{\circ} \mathrm{C}$ in humidified environment; $5 \% \mathrm{CO}_{2}$ and $95 \%$ humidity. In experiment II, COCs were incubated in standard in vitro fertilization (IVF) medium with the same concentrations for $24 \mathrm{hrs}$ in the same condition. In experiment III, COCs were incubated in standard in vitro culture (IVC) medium with the same concentrations for $24 \mathrm{hrs}$ in the same condition. According to the expansion of oocytes and attaining the developmental embryo stages of morula and blastocyst, our results have shown that addition of $20 \mathrm{ng} / \mathrm{ml}$ of EGF to the IVM medium significantly increased the oocyte maturation and fertilization rates compared to those of CTL (76.96 \pm 9.04 vs. $51.3 \pm 4.66$ and $67.96 \pm 2.76$ vs. $42.03 \pm 4.83 \%$, respectively $)(\mathrm{P}<0.05)$. On the other hand, Addition of $20 \mathrm{ng} / \mathrm{ml}$ of EGF to the IVM medium significantly increased the fertilization rates compared to other concentrations $(10$ and $50 \mathrm{ng} / \mathrm{ml})(67.96 \pm 02.76 \mathrm{vs} .49 .43 \pm 03.67$ and $34.70 \pm$ $01.40 \%$, respectively). However, the developmental rates to morula and blastocyst stages in response to addition to IVC medium variably increased rather than those of control despite no significance.

Keywords: Bubalus bubalis, Buffalo, EGF, IVM, Oocytes.

Received: September 27, 2018 Accepted: November 19, $2018 \quad$ Published: November 21, 2018 *Corresponding Author: Magdy Ramadan Badr E-mail:magdybadr69@yahoo.com

Citation: Yousef NA et al., Effect of Epidermal Growth Factors (EGF) on the Maturation and Developmental Competence of Buffalo's Oocytes and Embryo Stages in vitro. SVU-IJVS 2018, 1 (2): 85-94.

Copyright: (C) Yousef NA et al. This is an open access article distributed under the terms of the creative common attribution license, which permits unrestricted use, distribution and reproduction in any medium provided the original author and source are created.

Competing interest: The authors have declared that no competing interest exists. 


\section{Introduction}

Buffalos (Bubalus bubalis) are multipurpose animals for agriculture system as it not only provides milk, meat but also its value for labour and ability to resist environmental temperature, climate, stress and diseases (Ismail et al., 2016). However, buffaloes have low reproductive efficiency and limit the productivity which expressed in long post-partum anestrus period (Singh and Krishan, 1992), delayed age of puberty and low conception rates collectively (Nandi et al., 2002). The essential process for the optimal fertilization and developmental competence after oocytes maturation are resumption and completion of meiosis in mammalian oocytes are (Eppig, 1996). In addition, the nuclear and cytoplasmic maturation of oocytes are involved with the activation of oocytes, fertilization process and embryo development before implantation (Eppig et al., 1994) and it requires sufficient nutrients from follicular fluid and cells (Steeves and Gardner, 1999; Sutton-McDowall et al., 2005) as growth factors and hormones which promote nuclear and cytoplasmic maturation of oocytes (Mattioli et al., 1988; Procházka et al., 2000). Among growth factors, epidermal growth factor (EGF) plays an important role in cell growth, proliferation and differentiation by stimulation of mitosis in various types of cells (Yarden, 2001) and induces resumption of meiosis in mammalian oocytes (Bolamba et al., 2006; Lindbloom et al., 2008).

Hernandez et al. (1988) demonstrated that EGF participates in the regulation of many ovarian functions as a potent mitogen for granulosa cells, a biological amplifier of FSH action in the ovary and considered enhancer for oocyte maturation (Leibfried and First, 1979). The supplementation of maturation medium
(TCM-199) with EGF alone during in vitro maturation (IVM) at physiological concentrations stimulates cumulus cell expansion and improves the percentage of oocytes undergoing nuclear maturation (Lonergan et al., 1996). Despite numerous studies performed on the three main phases of in vitro embryo production (IVEP) (IVM, In vitro fertilization (IVF) and In vitro development (IVD), their efficacy is still low, with only 30 to $40 \%$ of oocytes developing into blastocysts (Camargo et al., 2006).

From all the above, the specific aim of this study was to assess the effects of EGF to IVM on the development competence of matured buffalo's oocytes, subsequent fertilization and developed embryos.

\section{Materials and Methods}

The present study was carried out at the IVF unit, Department of Artificial Insemination and Embryo Transfer, Animal Reproduction Research Institute (ARRI), EL-Haram, Giza, Egypt. All procedures in this study were conducted according to the Animal Ethics Committee of the South Valley University for Veterinary Research, Qena, Egypt.

\section{Collection of ovaries:}

Three hundred seventy ovaries (370) were collected from apparently healthy buffaloes with normal reproductive tracts and unknown breeding histories were slaughtered in El Monieb, Giza slaughterhouse. The ovaries were collected within 30 minutes after slaughter of the animals. The specimens were placed in a thermos containing normal saline $(0.9 \%$ $\mathrm{NaCl}$ with $100 \mathrm{IU} / \mathrm{ml}$ Penicillin and 100 $\mu \mathrm{g} / \mathrm{ml}$ Streptomycin) at a temperature of $35^{\circ} \mathrm{C}$ to preserve the viability of the ovaries during the period of transportation to the lab. The samples were transported to the laboratory within $1 \mathrm{hr}$. The ovaries were 
washed several times in a warm $0.9 \%$ $\mathrm{NaCl}$ solution at $37^{\circ} \mathrm{C}$ until obtaining clear transparent saline free from blood and then kept in a water bath at $37^{\circ} \mathrm{C}$ during the oocytes collection. The follicular fluids were aspirated from follicles ( 3 to $8 \mathrm{~mm}$ ) using a 16 gauge needle attached to a 10 $\mathrm{ml}$ syringe filled with aspiration media (TCM-199). The follicular fluids containing oocytes were pooled in a sterile $50 \mathrm{ml}$ centrifuge tube and were allowed to settle for $30 \mathrm{~min}$ at $37^{\circ} \mathrm{C}$. After settling, about $5 \mathrm{ml}$ of the sediment was aspirated and placed in a 10 cm-diameter polystyrene sterile Petri dish. Four hundred and seventy cumulus oocytes complexes (COCs) with compact multilayered cumulus investment and evenly granulated cytoplasm (Grade 1 as described by Chauhan et al., 1998) were selected for in vitro maturation. The oocytes were picked up with a sterile glass pipette under a stereomicroscope and transferred to another dish containing washing medium TCM-199.

\section{Experimental design and IVM:}

Oocytes with compact multilayered cumulus were divided into three major experiments according to addition of EGF. In experiment I, COCs were incubated in EGF-containing IVM medium as; 0 (control or CTL), 10, 20 and $50 \mathrm{ng} / \mathrm{ml}$ EGF for $24 \mathrm{hrs}$ at $38.5^{\circ} \mathrm{C}$ in humidified environment; $5 \% \mathrm{CO} 2$ and $95 \%$ humidity. In experiment II, COCs were incubated in standard IVF medium as; 0 (control or CTL), 10, 20 and $50 \mathrm{ng} / \mathrm{ml}$ EGF for $24 \mathrm{hrs}$ in the same condition. In experiment III, COCs were incubated in standard IVC medium as; 0 (control or CTL), 10, 20 and $50 \mathrm{ng} / \mathrm{ml}$ EGF for $24 \mathrm{hrs}$ in the same condition.

The $\mathrm{pH}$ of all media was adjusted to 7.4 and all media were filtered through 0.2 $\mu \mathrm{m}$ filter (Pal life Sciences, Ann Arbor,
USA) just before use. The cumulus oocyte complexes were washed several times with the IVM medium and groups of 10-15 COCs were placed in $50 \mu \mathrm{l}$ droplets of the IVM medium, covered with sterilized mineral oil in a 35- $\mathrm{mm}$ Petri dish and cultured for $24 \mathrm{hrs}$ under $5 \% \mathrm{CO} 2$ at 38.5 ${ }^{\circ} \mathrm{C}$.

\section{In vitro fertilization:}

For IVF of matured buffalo oocytes, oocytes matured in maturation medium were partially denuded from the surrounding cumulus cells to allow easy penetration of the sperm cells. They were washed twice in pre-warmed fertilization medium to maintain the defined component of the IVF media and IVM oocytes were fertilized in vitro TALP media. The matured oocytes were washed with F-TALP and partially denuded. The frozen semen straws form artificial insemination unit at ARRI, selected by swim up and incubated with caffeine (3.83 $\mathrm{mg}$ ) for capacitation. About 5-15 matured oocytes were placed in each well of a culture dish containing $75 \mu \mathrm{l}$ of fertilization media, to which $25 \mu$ of sperm suspension (motile spermatozoa (10 x 106 separated by swim up using sperm TALP medium) were added, they were covered with sterile mineral oil and placed in a $\mathrm{CO} 2$ incubator (Forma Scientific, Inc.comp., 35485/NModel) at $38.5{ }^{\circ} \mathrm{C}$ for 20-22 hrs (Parrish et al., 1986). At the end of this stage, the penetration rate in which the rate of oocytes penetrated by the sperms, and the subsequent fertilization rate in which the rate of successful fertilization of oocytes were recorded.

\section{$I V$. In vitro culture:}

At the end of sperm-oocyte incubation, prior to the transfer to the IVC droplets, presumed zygotes were washed four times in embryo culture medium 
(SOF) and cultured in this medium in a humidified $\mathrm{CO} 2$ incubator at $38.5^{\circ} \mathrm{C}$.

The embryo production rate was examined under Stereomicroscope (nanshige, Nikon, SM. DIA, Japan) to record the number of cleaved embryos at 8-16 cells after 94-96 hrs post insemination. Cleavage was recorded after $72 \mathrm{hrs}$ of culture (day 0=day of insemination) and the embryos developing to the morula and blastocyst stages were assessed at days 5 and 7, respectively.

\section{Statistical analysis:}

Each experiment was replicated at least three times. Data were presented as mean and standard error (mean \pm SEM). Statistical significance was determined by analysis variance (One-Way ANOVA and t-test) by Graph pad Prism, Version 5 for confirm the significance. Statistically significant differences values were set at $\mathrm{P}$ $\leq 0.05$.

\section{Results}

I. Experiment I: Effect of EGF-maturation medium on the buffalo oocytes maturation rate and embryo stages in vitro:

Ten, 20 and $50 \mathrm{ng} / \mathrm{ml}$ of EGF added to the maturation medium showed variable effects on the oocyte maturation rate (Expressed in expansion of the cumulus cells). The former two concentrations increased the maturation rate of the oocyte in vitro while the later concentration did not. Our results have shown that $20 \mathrm{ng} / \mathrm{ml}$ of EGF significantly increase in the maturation rate of oocytes $(\mathrm{P}<0.05)$ rather than other two concentrations compared to the control group $(76.96 \pm 9.04$ vs. $51.33 \pm$ $4.66 \%$ ) (Fig. 1A and Fig. 2).

II. Experiment II: Effect of EGFmaturation medium on the fertilization rate in vitro:
Twenty $\mathrm{ng} / \mathrm{ml}$ of EGF added to the maturation medium tended to significantly increased the penetration and fertilization rates of the oocytes compared to control $(65.49 \pm 3.83$ vs $61.66 \pm 2.56$ and $67.96 \pm$ 2.76 vs $42.03 \pm 4.83 \%$, respectively) (Fig. 1B).

III. Experiment III: Effect of EGFmaturation medium on the embryo stages in vitro:

Interestingly, in comparison to the control group, EGF increased the incidence of cleavage, morula stage and blastocyst formation and that the concentration 20 $\mathrm{ng} / \mathrm{ml}$ significantly increased the incidence of cleavage rate $(30.76 \pm 4.66$ vs $61.10 \pm$ $4.85 \%$, respectively), morula stage (27.76 \pm 14.69 vs $49.46 \pm 3.64 \%$, respectively) $(\mathrm{P}<0.05)$. While, $50 \mathrm{ng} / \mathrm{ml}$ of EGF highly increased the formation of morula stage than $20 \mathrm{ng} / \mathrm{ml}$ of EGF (61.13 \pm 5.56 vs $49.46 \pm 3.64 \%$, respectively). However, $20 \mathrm{ng} / \mathrm{ml}$ of EGF tended to significantly increase the formation of blastocyst compared to control $(58.90 \pm 4.85$ vs 50.00 $\pm 28.86 \%$, respectively) (Fig. $1 \mathrm{C}$ and Fig.3)

\section{Discussion}

To enhance Bubalus bubalis oocyte maturation rates, it is necessary to modify a suitable oocyte maturation medium with various supplements. The process of meiotic maturation and acquisition of developmental competence determine the ability of the oocytes to undergo successful fertilization, cleavage, and embryonic development. Little information is available on IVM and IVF of buffalo oocytes. In buffaloes, despite a similar maturation rate, a significantly lower cleavage rate was observed in comparison to cattle with 87 vs $94 \%$, and 65 vs $84 \%$, respectively (Gasparrini, 2002; Neglia et al., 2003). Therefore, it is a prompt concern to further improve IVEP so that it 
can be widely used for buffalo. These important steps are dependent on a variety of factors that lead to proper nuclear and cytoplasmic maturation (Trounson et al., 2001).

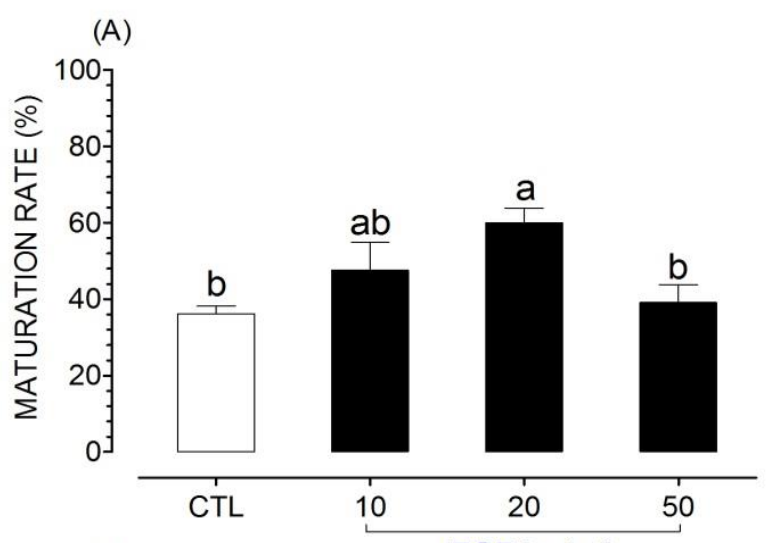

(B)

EGF (ng/ml)

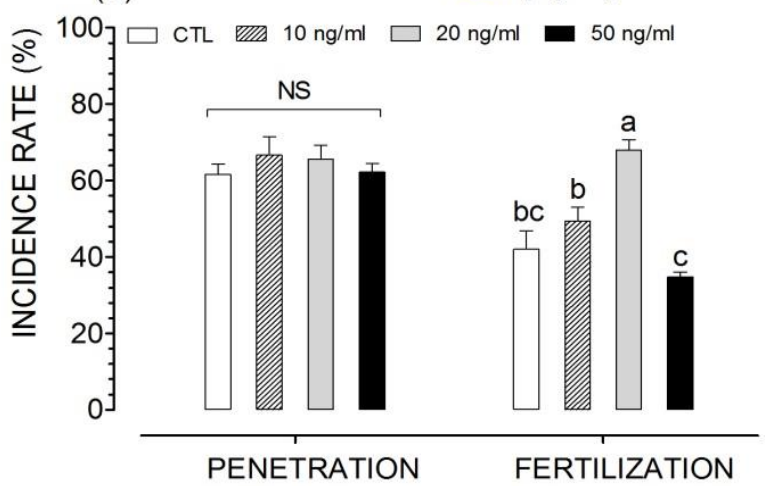

(C)

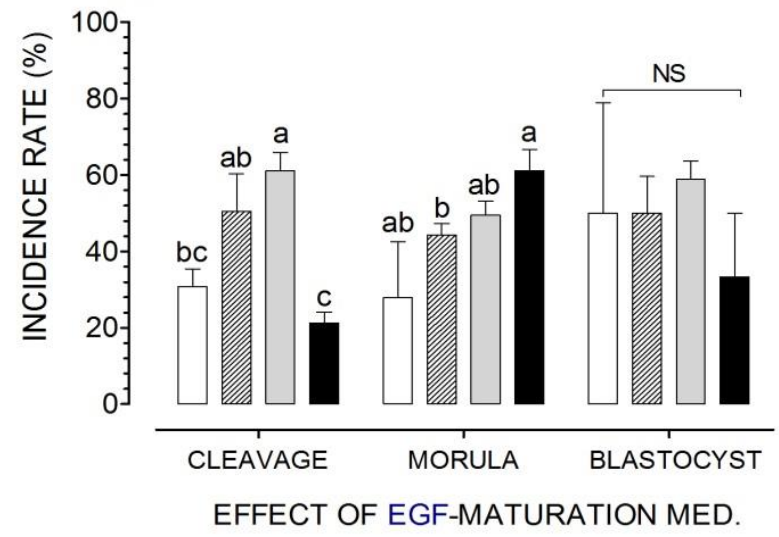

Fig. 1. The oocyte maturation rate, penetration/fertilization and the embryo stages in response to addition of epidermal growth factor (EGF) to the maturation medium in response to the EGF are shown in fig. $1 \mathrm{~A}, \mathrm{~B}$ and $\mathrm{C}$, respectively. The EGF maturation medium was used in variable conc. according to the groups of treatment: 0 (vehicle), 10, 20 and $50 \mathrm{ng} / \mathrm{ml}$ were used in the control and treated groups. The total number $(\mathrm{n})$ of oocytes used were 47, 46, 48 and 43 in fig. 1A, 34, 36, 38 and 37 in fig. 1B and 29, 37, 40 and 38 in fig. 1C per each respective group. All data were presented as mean \pm SEM. The letters on bar $(\mathrm{a}, \mathrm{b}$ and $\mathrm{c}$ ) denote significant difference at $\mathrm{P}<0.05$. 

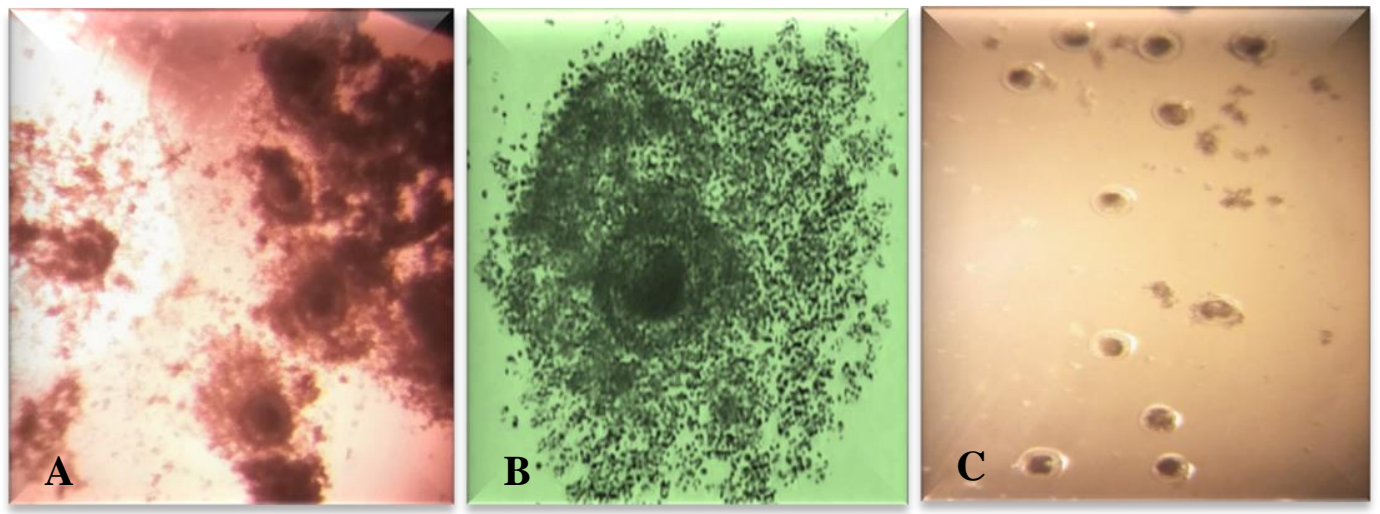

Fig. 2. In vitro matured oocytes. In vitro matured oocytes with expanded cumulus mass (A) and (B) and denuded oocytes after washing three times in F-TALP medium (C).
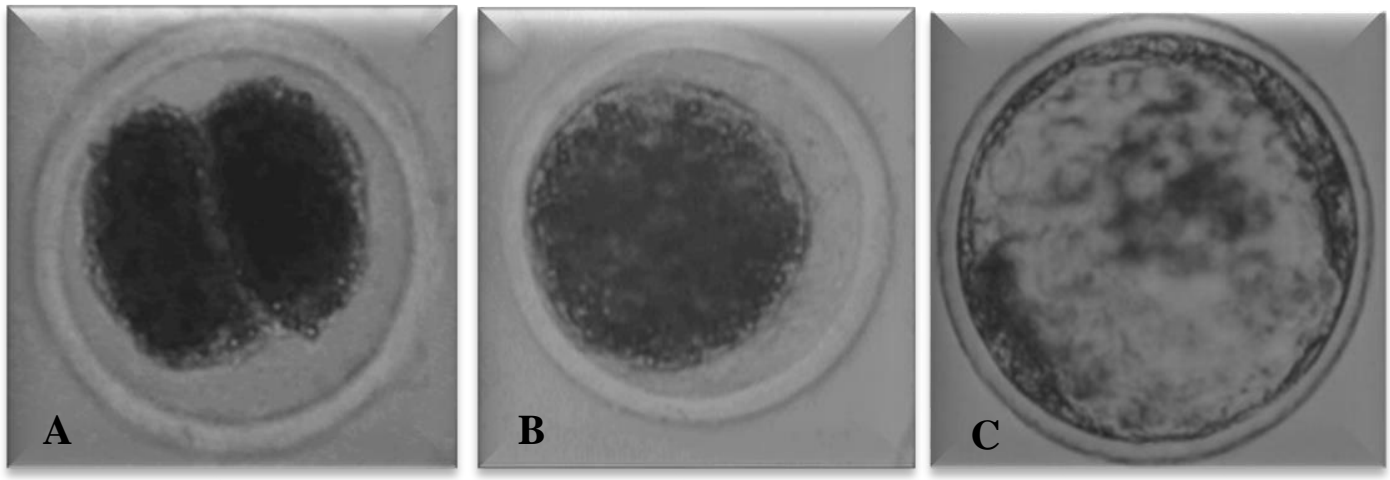

Fig. 3. Evaluation of the cleavage rate, morula and blastocyst formation. Cleaved oocyte with 2 cell stage (A), compact morula (B) and expanded blastocyst (C).

Growth factors as EGF may be represented as local regulators in the coordination of cellular proliferation and differentiation. In that regard, EGF stimulates cellular functions which effect on early development of mammalian embryos (Teruel et al., 2000). The present study demonstrated that EGF enhanced cumulus expansion in buffalo cumulus oocyte complexes. The present study recorded that $20 \mathrm{ng} / \mathrm{mL}$ EGF was more beneficial on embryo development than other two examined concentrations (10 and 50 $\mathrm{ng} / \mathrm{ml}$ ). Our findings were similar to other researchers reported that EGF was contributed to the promotion of oocyte maturation (Downs, 1989; Sanbuissho et al., 1991). The results of the present study revealed that the IVM supplemented with EGF $(20 \mathrm{ng} / \mathrm{ml})$ increased the oocyte maturation, fertilization, cleavage, morula and blastocyst production rates. These results were similar to other studies achieved by Singhal et al., (2009) and Mishra et al., (2010) which used EGF as supplements during IVM of buffalos' oocytes. Moreover, EGF supplementation to the IVM media doubled the blastocyst formation rate (13 to 27\%) (Grazul- Bilska et al., 2003). In addition, our findings supported the results reported by Kandil et al. (2013) and Sadeesh et al. (2014) which mentioned that the optimum concentration of EGF added to the IVM media was 20 $\mathrm{ng} / \mathrm{ml}$ concentration to maintain better 
development of buffalo embryos. Other groups stated that oocytes maturation and embryo development rate were increased at concentration $10 \mathrm{ng} / \mathrm{ml}$ EGF in several animal species as cow (Lonergan et al., 1996 and Mtango et al., 2003) and buffalo (Kumar and Purohit, 2004 and Purohit et al., 2005). Moreover, Sirisathien et al. (2003); Thongkittidilok et al. (2015) and El-Naby et al. (2016) observed that oocyte competence and blastocyst developmental rate were improved at a concentration of 5 $\mathrm{ng} / \mathrm{ml}$ EGF compared with the control group. While the present study recorded that the low concentrations as $10 \mathrm{ng} / \mathrm{ml}$ decrease the maturation and embryo development compared to $20 \mathrm{ng} / \mathrm{ml}$.

In accordance to our study, Carpenter and Cohen, (1976) and Sirotkin et al., (2000) stated that higher concentrations $(40 \mathrm{ng} / \mathrm{ml})$ of EGF reduced the blastocyst development which is likely due downregulation of the EGF-induced receptor. The blastocyst development decreased at a higher concentration of EGF $(50 \mathrm{ng} / \mathrm{ml})$. Thus the presence of high concentration of EGF caused a significant down regulation of the EGF-induced receptors or acceleration of EGF receptors degradation (Beguinot et al., 1984). In another study using sheep, $\mathrm{Ni}$ et al. (2015) proved that in vitro embryo developmental rate was significantly higher at concentration of $50 \mathrm{ng} / \mathrm{ml}$ EGF. While, the suitable concentration for mouse embryo development was $1 \mathrm{ng} / \mathrm{ml}$ EGF (Merriman et al., 1998).

\section{Conclusion}

From the present study, it was concluded that addition of EGF at 20 $\mathrm{ng} / \mathrm{ml}$ concentration in IVM media enhance the maturation of oocyte, fertilization and developed embryos. Addition of EGF to the maturation medium had an economic value owing to increase the percent of developed embryos compared to the control group.

\section{Acknowledgment}

The authors would like to thank all members of the IVF Unit, Department of Artificial Insemination and Embryo Transfer, Animal Reproduction Research Institute (ARRI), EL-Haram, Giza, Egypt and all members of Department of Theriogenology, Obstetrics, and Artificial Insemination, Faculty of Veterinary Medicine, South Valley University, Qena, Egypt for their help, assistance, and support.

\section{References}

Beguinot L, Liall RM, Willingham MC, Pastan I (1984). Down-regulation of the epidermal growth factor receptor in $\mathrm{KB}$ cells is due to receptor internalization and subsequent degradation in lysosomes. Proceedings of the National Academy of Science, 81: $2384-2388$.

Bolamba D, Russ KD, Harper SA, Sandler JL, Durrant BS (2006). Effects of epidermal growth factor and hormones on granulosa expansion and nuclear maturation of dog oocytes in vitro. Theriogenology, 65:1037-1047.

Camargo LSA, Viana JHM, Sa WF, Ferreira AM, Ramos AA (2006). Factors influencing in vitro embryo production. Animal Reproduction, 3: 19 - 28.

Carpenter G and Cohen S (1976). ${ }^{125} \mathrm{I}-$ Labeled human epidermal growth 
factor: Binding, internalization, and degradation in human fibroblasts. Journal of Cellular Biology, 71: $159-171$.

Chauhan MS, Singla SK, Palta P, Manik RS, Madan ML (1998). In vitro maturation and fertilization, and subsequent development of buffalo (Bubalus bubalis) embryos: effects of oocyte quality and type of serum. Reproduction and Fertility Development, 10: 173 - 177.

Downs SM (1989). Specificity of epidermal growth factor action on maturation of the murine oocyte and the cumulus oophorusin vitro. Biology of Reproduction, 41: 371 379.

El-Naby AAH, Mahmoud KGhM, Scholkamy TH, Ahmed YF, Sosa GAM, Abouel-Roos MEA (2016). Influence of Epidermal Growth Factor with Cysteamine on in Vitro Buffalo Embryo Development. Egyptian Journal of Veterinary Science, 47: 27 - 39.

Eppig JJ (1996). Coordination of nuclear and cytoplasmic oocyte maturation in eutherian mammals. Reproduction and Fertility Development, 8: 485 - 489.

Eppig JJ, Schultz RM, O'Brien M, Chesnel F (1994). Relationship between the developmental programs controlling nuclear and cytoplasmic maturation of mouse oocytes. Development Biology, 164: 1 - 9.

Gasparrini B (2002). In vitro embryo production in buffalo species: state of the art. Theriogenology, 57: 237-256.

Grazul-Bilska AT, Choi JT, Bilski JJ, Weigl RM, Kirsch JD, Kraft KC, Reynolds LP, Redmer DA (2003). Effects of epidermal growth factor on early embryonic development after in vitro fertilization of oocytes collected from ewes treated with follicle stimulating hormone. Theriogenology, 59: 1449 - 1457.

Hernandez ER, Resnick CE, Svoboda ME, van Wyk, JJ, Payne DW, Adashi E Y (1988). Somatomedin-C/insulinlike growth factor-I as an enhancer of androgen biosynthesis by cultured rat ovarian cells. Endocrinology, 122:1603-1612.

Ismail EA, Elsayed MAI, Hemeida NA, Abdoon, ASS, Kandil OM (2016). Effect of Insulin-Like Growth Factor-I (IGF-1) on oocyte competence and embryo development of buffaloes (Bubalus Bubalis). International Journal of Chemistry Technology Research, 9: $738-748$.

Kandil OM, Abdoon ASS, Kacheva CHD, Georgiev B (2013). Effect of in vitro culture media on embryo developmental competence and vitrification methods in blastocyst viability in buffalo. Global Veterinary, 11: 622 - 629.

Kumar D and Purohit GN (2004). Effect of epidermal and insulin-like growth factor-1 on cumulus expansion, nuclear maturation and fertilization of buffalo cumulus oocyte complexes in simple serum free media DMEM and Ham's F-10. Veterinary Archive, 74: 13 - 25.

Leibfried ML and First NL (1979). Characterization of bovine follicular oocytes and their ability to mature in vitro. Journal of Animal Science, 48:76-86.

Lindbloom S, Farmerie T, Clay C, Seidel G, Carnevale E (2008). Potential involvement of EGF-like growth factors and phosphor diesterases in initiation of equine oocyte maturation. Animal Reproduction Science, 103:187-192. 
Lonergan P, Carolan C, van Langendonckt A, Donnay I, Khatir H, Mermillod P (1996). Role of epidermal growth factor in bovine oocyte maturation and preimplantation embryo development in vitro. Biology of Reproduction, 54: 1420 - 1429.

Mattioli M, Galeati G, Seren E (1988). Effect of follicle somatic cells during pig oocyte maturation on egg penetrability and male pronucleus formation. Gamete Research, 20: 177 - 183.

Merriman JA, Whittingham DG, Carroll J (1998). The effect of follicle stimulating hormone and epidermal growth factor on the developmental capacity of in-vitro matured mouse oocytes. Human Reproduction, 13: $690-695$.

Mishra A, Chandra V, Sharma GT (2010). Effect of epidermal growth factor on in-vitro maturation of buffalo oocytes and subsequent development with insulin-like growth factor-1 and Bmercaptoethanol. Indian Journal of Animal Science, 8: 721-724.

Mtango NR, Varisanga MD, Dong YJ, Rajamahendran R, Suzuki T (2003). Growth factors and growth hormone enhance in vitro embryo production and post -thaw survival of vitrified bovine blastocyst. Theriogenology, 59: 1393 - 1402.

Nandi S, Raghu HM, Ravindranatha BM, Chauhan MS (2002). Production of buffalo (Bubalus bubalis) embryos in vitro: premises and promises. Reproduction Domestic Animal, 37: 65-74.

Neglia G, Gasparrini B, Caracciolo di Brienza V, Di Palo R, Campanile G, Presicce GA, Zicarelli L (2003). Bovine and buffalo in vitro embryo production using oocytes derived from abattoir ovaries or collected by transvaginal follicle aspiration. Theriogenology, 59: 1123 - 30.

Ni H, Sheng X, Cui X, Gu M, Liu Y, Qi X, Xing S, Guo Y (2015). Epidermal growth factor-mediated mitogenactivated protein kinase $3 / 1$ pathway is conducive to in vitro maturation of sheep oocytes. PLoS ONE, 10: 20418.

Parrish JJ, Susko-Parrish JL, LeibfriedRutledge ML, Critser ES, Eyestone WH, First NL (1986). Bovine in vitro fertilization with frozenthawed semen. Theriogenology, 25:591 - 600.

Procházka R, Sršeň V, Nagyová E, Miyano T, Flechon JE (2000). Developmental regulation of effect of epidermal growth factor on porcine oocyte-cumulus cell complexes: Nuclear maturation, expansion, and F-actin remodeling. Molecular Reproduction Development, 56: 63 - 73.

Purohit GN, Brady MS, Sharma SS (2005). Influence of epidermal growth factor and insulin-like growth factor 1 on nuclear maturation and fertilization of buffalo cumulus oocyte complex in serum free media and their subsequent development in vitro. Animal Reproduction Science, 87: 229-239.

Sadeesh EM, Shah F, Balhara AK, Thirumaran SMK, Yadav S, Yadav PS (2014). Effect of growth factor and antioxidant on in vitro maturation of oocytes and cleavage rates of in vitro produced Indian buffalo (Bubalus bubalis) embryos. Veterinarski Archive, 84: 459-474.

Sanbuissho A, Coskun S, Lin YC (1991). Stimulatory action of epidermal growth factor on in vitro bovine oocyte maturation. Assisted Reproductive Technology of Andrology, 1:143-153. 
Singh B and Krishan L (1992). Effect of season and breed on certain reproductive traits in buffaloes under village conditions. Indian Journal of Animal Research, 26: 1519.

Singhal S, Prasad S, Singh B, Prasad JK, Gupta HP (2009). Effect of including growth factors and antioxidants in maturation medium used for in vitro culture of buffalo oocytes recovered in vivo. Animal Reproduction Science, 113: 44-50.

Sirisathien S, Hernandez-Fonseca HJ, Brackett BG (2003). Influences of epidermal growth factor and insulinlike growth factor-I on bovine blastocyst development in vitro. Animal Reproduction Science, 77: 21-32.

Sirotkin AV, Dukesova J, Makarevich AV, Kubek A, Bulla J (2000). Evidence that growth factors IGF-I, IGF-II and EGF can stimulate nuclear maturation of porcine oocytes via intracellular protein kinase A. Reproduction and Nutrition Development, 40: 559-569.

Steeves $\mathrm{T}$ and Gardner D (1999). Metabolism of glucose, pyruvate, and glutamine during the maturation of oocytes derived from pre-pubertal and adult cows.
Molecular Reproduction

Development, 54: 92 -101.

Sutton-McDowall ML, Gilchrist RB, Thompson JG (2005). Effect of hexoses and gonadotropin supplementation on bovine oocyte nuclear maturation during in vitro maturation in a synthetic follicle fluid medium. Reproduction Fertility Development, 17: 407-415.

Teruel M, Smith R, Catalano R (2000). Growth factor: An embryo development. Biocell, 24: 107 - 122.

Thongkittidilok C, Tharasanit T, Songsasen N, Sananmuang T, Buarpung S, Techakumphu M (2015). Epidermal growth factor improves developmental competence and embryonic quality of singly cultured domestic cat embryos. Journal of Reproduction Development, 61: 269 - 276.

Trounson A, Anderiesz C, Jones G (2001). Maturation of human oocytes in vitro and their developmental competence. Reproduction, 121: 5175.

Yarden Y (2001). The EGFR family and its ligands in human cancer: signalling mechanisms and therapeutic opportunities. European. Journal of Cancer, 3. 